DOI https://doi.org/10.30525/978-9934-588-81-5-1.3

\title{
MODERN APPROACH TO TREATMENT OF POST-INFECTION COUGH HYPERSENSITIVITY SYNDROM
}

\author{
Baranova I. V. \\ Candidate of Medical Sciences, \\ Associate Professor at the Department of Rehabilitation Medicine \\ and Medical-Social Expertise \\ National Pyrogov Memorial Medical University \\ Iliuk I. A. \\ Candidate of Medical Sciences, \\ Associate Professor at the Department of Internal Medcine № 2 \\ National Pyrogov Memorial Medical University \\ Solyeyko O. V. \\ Doctor of Medical Sciences, \\ Professor at the Department of Internal Medcine № 2 \\ National Pyrogov Memorial Medical University \\ Postovitenko K. P. \\ Candidate of Medical Sciences, \\ Associate Professor at the Department of Rehabilitation Medicine \\ and Medical-Social Expertise \\ National Pyrogov Memorial Medical University \\ Prykhodko N. M. \\ Doctor Intern at the Department of Internal Medcine \\ of the Medical Faculty № 2 \\ National Pyrogov Memorial Medical University \\ Vinnytsia, Ukraine
}

Problem statement: search for new methods of treatment of postinfectious cough hypersensitivity syndrome (PCHS) is a very topical problem of practical medicine [4, p. 1715]. A review of literature data of studies highlighting the efficiency of nebulizer therapy with the use of drugs of reparative action, and namely, hyaluronic acid solution in the treatment of PCHS, showed that such studies have not been found and, therefore, this area of therapy requires a more detailed study.

Study objective: to optimize the treatment of patients with postinfectious cough hypersensitivity syndrome by way of applying nebulizer therapy with $0,1 \%$ solution of sodium hyaluronate and to study the dynam- 
ics of quality of life indicators in patients as well as adaptive responses of the organism in case of this pathology.

Methods and Materials: The study was prospective and controlled. By the method of free choice, the patients were divided into two groups: the main (group 1) and the comparison group (group 2). The study design was approved by the Bioethics Commission of National Pirohov Memorial Medical University, Vinnytsya, (Protocol № 10 as of November 23, 2017). The research plan involves the prescription of antitussive drugs for all patients in the recommended daily dosage. Besides, persons in the main group additionally underwent nebulizer therapy with $0,1 \%$ solution of hyaluronic acid (HA) twice a day with a cycle of treatment consisting of 12-16 sessions. The final points of the study were: improvement of quality of life indicators, achievement of the state of subjective health by the patients, reduction of terms of temporary disability of patients with PCHS.

We have examined 66 patients aged from 19 to 52 years who were diagnosed with PCHS at the municipal institution "City Clinical Hospital № 2 of the city of Vinnytsya". Group 1 (main group) included 33 patients and group 2 (comparison group) also included 33 patients. Groups were representative by age and gender. Cycles of the performed drug treatment corresponded to protocols of the Ministry of Public Health [2, p. 19-20]. The effect of treatment in patients was determined using quality of life evaluation, i.e. an adapted questionnaire SF-36, available on the website of Evidence Company "Clinical and Pharmacological Research". According to the instructions of this company, a statistical processing of data was performed [3, p. 17-18]. The scale allows to evaluate physical and mental health levels. The questionnaire was filled out independently by the patient twice - at the beginning of the treatment and two weeks after the treatment. For comparison, we used study outcomes received by domestic authors who used SF-36 in 52 apparently healthy adult respondents. To summarize the outcomes, the following was taken into account: physical health, physical functioning, physical role function, pain intensity, general state of health. Other 4 indicators and, namely, mental health, psychological role function, social functioning and vital activity form mental health. Besides, for rapid assessment of therapy efficacy, patients were asked to determine independently their health status on the 5, 10 and the 15 day of treatment according to the following scale: "health deterioration", "no change", "improvement", "significant improvement", "consider myself apparently healthy". At the beginning of the treatment and two weeks later, the patients determined their functional status according to the differential cough score scale for assessment of cough by force and frequency. The period of temporary disability was taken into consideration as well. Typing of adaptive responses of the organism (ARO) was performed according to the classical method of L. Kh. Harkavi $[1, \mathrm{p} .15,16]$ before treatment, on the 
5 and the 15day of treatment. The reliability of obtained outcomes was determined using Student's criterion (package Stat Soft Statistica v.6.0.). The outcomes with an error $\mathrm{p}<0,05$ were considered as reliable.

Outcomes: Since the 10th day of treatment antitussive drugs were canceled in $39,4 \%$ of patients in the main group, and they proceeded to work. In the comparison group 45,5\% of patients still continued taking antitussive drugs on the 15 th day of treatment and could not perform their professional duties on a full scale (if prolonged linguistic communication was required). The average duration of temporary disability in the persons that underwent a combination treatment which involved the use of nebulizer therapy with a solution of HA was $12 \pm 1,7$ days, and in the patients who took just antitussive drugs it was $18 \pm 2,9$ days. The expediency of pathogenetic direction of dry cough therapy is emphasized by the significant advantage $(p<0,05)$ of combination treatment plan in the main group. In contrast with the comparison group after the use of HA solution inhalation form the outcomes of the undertaken study was the recovery and restoration of patients' quality of life (according to the questionnaire SF-36) in a significantly short time $(\mathrm{p}<0,01)$. Under the influence of complex treatment that included nebulizer therapy with HA solution in patients with PCHS, a more significant elevation in the number of increased activation responses $(p<0,001)$ (favourable responses) was observed in contrast with similar data in the control group. The dynamics of ARO of the same type confirms the presence of full remission in patients. In persons who received traditional therapy, a significant increase in the number of chronic stress and fight-or-flight responses $(p<0,01)$ (unfavourable responses) was observed in contrast with the main group. These changes are a marker of incomplete remission.

Conclusions. Combination treatment with application of $0,1 \%$ solution of sodium hyaluronate has a pathogenetic significance. Rational combination of drugs and nebulizer way of introduction of hyaluronic acid allows to eliminate the symptoms of disease within a short term, restore the patients' quality of life and achieve full remission of post-infectious cough hypersensitivity syndrome.

Further study and determination of the type of general non-specific adaptive response of the organism as a criterion of efficacy of the conducted treatment and dividing the patients into groups are promising (for example, into groups of patients who require additional curative measures, those who have fully recovered and those who are healthy).

\section{References:}

1. Гаркави ЛХ, Квакина ЕБ. Понятие здоровья с позиции теории неспецифических адаптационных реакций организма. Валеология. $1996 ; 2: 15-20$ 
2. Кашель. Адаптована клінічна настанова, заснована на доказах. 2015. 94 c. URL: http://www.volpulmonology.com.ua.

3. Лещенко СI, Моногарова СН. Показники якості життя у хворих на ідіопатичні інтерстиціальні пневмонії. Укр. пульмонолог. журн. 2008;1:17-22.

4. Peter SP Cho, Surinder S Birring, Hannah V Fletcher, et al. Methods of Cough Assessment. The Journal of Allergy and Clinical Immunology: In Practice. 2019;7(6):1715-1723. https://doi.org/10.1016/j.jaip. 2019.01.049.

DOI https://doi.org/10.30525/978-9934-588-81-5-1.4

\title{
ВПЛИВ ПЕРВИННОЇ ДИСМЕНОРЕЇ НА ЯКІСТЬ ЖИТТЯ УЧЕНИЦЬ СТАРШИХ КЛАСІВ ШКІЛ МІСТА
}

\author{
Басюга I. O. \\ кандидат медичних наук, \\ дочент кафедри акушерства і гінекології імені I. Д. Ланового \\ Івано-Франківський національний медичний університет \\ Жураківський В. М. \\ кандидат медичних наук, \\ дочент кафедри акушерства і гінекології імені I. Д. Ланового \\ Івано-Франківський національний медичний університет \\ Моцюк Ю. Б. \\ кандидат медичних наук, \\ асистент кафедри акушерства і гінекології імені І. Д. Ланового \\ Івано-Франківський національний медичний університет \\ Матвійків Н. I. \\ кандидат медичних наук, \\ асистент кафедри акушерства і гінекології ПО \\ Івано-Франківський національний медичний університет \\ м. Івано-Франківськ, Украӥна
}

Первинна дисменорея є однією з найбільш розповсюджених скарг i гінекологічних проблем серед молодих жінок. Звісно дане захворювання не $\epsilon$ справжньою загрозою життю, однак здатне впливати на якість життя дівчат і в залежності від тяжкості перебігу може призводити до тимчасової недієздатності. 3 іншого боку, дисменорея є причиною емоційно-психічних порушень у деяких жінок, що проявляєть- 